\title{
THE ROLE OF NEFERTITI IN THE RELIGION AND THE POLITICS OF THE AMARNA PERIOD
}

\author{
ROLA NEFERTITI W RELIGII I POLITYCE \\ OKRESU AMARNEŃSKIEGO
}

\author{
Maria Kloska \\ Instytut Archeologii, Wydział Historyczny, Uniwersytet im. Adama Mickiewicza \\ ul. Umultowska 89D, 61-614 Poznań, Poland \\ Madame_16@poczta.fm
}

\begin{abstract}
Nefertiti, the wife of Pharaoh Akhenaten, fulfilled several important functions in both the religion and politics of the Amarna Period.

The very name of Nefertiti, Nfr-nfr.w-jtn nfr.t-jj.tj, which translates as The Beautiful is Beauty of Aten, The Beautiful One Has Come, shows how important was the role she played in representing the qualities of the sun god Akhetaten.

Nefertiti was presented as The Great Wife of the King but also The Lady of the Two Lands. These titles are indicative of her strong position in politics, because in ancient Egypt, religion and ideology of royal power were inextricably linked.

Apparently, the queen was identified with the ruler. This is evidenced, for example, in the scenes from talatat, where Nefertiti was presented on the board of a ceremonial ship pulling a captive by his or her hair and massacring him or her with a khepesh sword, held in the other hand.

Very important is the sacral dimension of Nefertiti, because apart from holding significant religious and political functions, she was also deified. Nefertiti's divine status is best illustrated and confirmed in Akhenaten's sarcophagus. At each corner, the queen is shown with outstretched arms, covering and protecting the deceased ruler.

Recent discoveries in great Wadi Dayr Abu Hinnis indicate that in 16 Year of Akhenaten's reign, Nefertiti was still alive and was the highest queen. This sheds new light on the Amarna Period. It cannot be ruled out that Nefertiti, as Ankhkheperure Neferneferuaton, held the function of Akhenaten's coregent, and after her husband's death, ruled independently as Anchcheperure Semenchakare.
\end{abstract}

KEY WORDS: Nefertiti, Amarna Period, origin of Nefertiti, titulary of Nefertiti, political role, religious role, Anchcheperure Neferneferuaton, Ankhkheperure Semenkhkare 
The main aim of this paper is to discuss and analyse the sources in order to determine the place of Nefertiti in both the religion and politics of the Amarna Period. The paper also looks at the queen's role in Akhetaten. I intend to present the most convincing evidence confirming my assumptions, according to which Nefertiti reigned alongside her husband, and after his death, took over as Semenkhare. A lot of data indicates that the queen was perceived as a goddess, and she certainly played the role of a protective deity of her husband's body.

Nefertiti, the wife of pharaoh Akhenaten, was certainly an outstanding queen. In comparison to the other Great Royal Wives, she stands out like Hatshepsut or Tiye.

Nefertiti played an important role in the religion and politics of the Amarna Period. The name of the queen, ${ }^{1}$ Nfr-nfr.w-jtn nfr.t-jj.tj, ${ }^{2}$ meaning The Beautiful is Beauty of Aten, The Beautiful One Has Come, shows how important role she played in representing the qualities of the sun god (Gardiner 1957, p. 574) ${ }^{3}$.

\section{THE ORIGIN OF NEFERTITI}

Nefertiti, like queen Tiye, originated from a non-royal family. Since the inscriptions and documents do not provide direct information about her origin, Egyptologists put forward various views on this subject. In addition, the name of Nefertiti inspired theories about her non-Egyptian roots. These suggestions were very tempting, because they would explain the introduction of new, monotheistic beliefs into the conservative Egyptian court .

Nefertiti was identified with the daughter of the king Tushratta of Mitanni, Tadukhipa (Reeves 2001, p. 88). The main arguments that had supported this idea were the name of the queen and the fact that the Mitannian princess was the youngest of the foreign brides of the pharaoh. Tadukhipa came to Egypt to marry Amenhotep III, who had died before she arrived to the Egyptian court. Most probably, she was incorporated into Akhenaten's harem and since then the Egyptian inscriptions did not mention her. However, at the same time the name of Nefertiti appeared in the inscriptions. Consequently, the theory was born, according to which the princess and the queen were the same person (Tyldesley 2003, p. 50). Admittedly, in the time of the XX dynasty Ramesses II married princess Shauska-Nu, the daughter of the king of Mitanni, in the context of the peace treaty. The princess was given an Egyptian name Maat-hor-neferu-re and became The Great Wife of the King (Schlögl 2009,

\footnotetext{
${ }^{1}$ Parallels to the name of the queen are known from the earlier periods, eg. Nfr.w-sbk (the last ruler of the XII dynasty) or Nfr.w-ra (daughter of the female pharaoh Hatshepsut).

${ }^{2}$ Transliterations and translations, which do not have references to literature, have been made by the author.

${ }^{3}$ The word nfr means be good, be beautiful, be perfect.
} 
p. 231). However, there is no evidence in the case of Nefertiti indicating that was a similar precedent for Amarna queen.

According to another hypothesis, Nefertiti would be a daughter of Satamon ${ }^{4}$. This, however, seems impossible since Satamon married her own father Amenhotep III when he was old, so she could not have a daughter, who would be adult enough to marry Akhenaten in the future (Tyldesley 2003, p. 55). Besides, Nefertiti did not use the title of The King's Daughter.

Nowadays, more and more evidence indicates that the queen came from the Egyptian elite. Nefertiti was probably a daughter of Ay, who later became the king of Egypt. Ay was the son of Yuya and Tjuyu, and the brother of the queen Tiye - the wife of the king Amenhotep III. Yuya and Tjuyu belonged to the educated and rich Egyptian elite. Yuya's titles were The Overseer of the King's Horses and The Father of God. He was also the priest of the god Min. Tjuyu played various functions at the royal court. Most often she used the title of The Royal Mother of the Great Wife of the King. Yuya and Tjuyu were also the parents of Aanen, who was the priest in Heliopolis. Ay bore the title of The Father of God. If we translate this title literally, it turns out that he was the father-in-law of the king, so he was father of the king's wife. Ay was the husband of Tiy, who purports to be the fostermother of Nefertiti (Tyldesley 2006, pp. 125-126), but she never referred to herself as The Royal Mother of the Great Wife of the King, like Tjuyu wrote about herself. We can conclude that after the birth of his daughter, Ay was widowed and re-married (Tiy would be his second wife), although we never find a mention of his first wife. In the Amarna tomb of Ay in the court (Davies 1908, vol. VI, pl. XXIX), there is a relief showing Akhenaten, Nefertiti and their three daughters in the so-called Window of Appearances. The royal couple donates Ay and his wife Tiy golden necklaces. Initially, it was the way to distinguish victorious warriors of the pharaoh's army. However, since the XVIII dynasty this custom included also high-ranking royal officials. The gift of gold was a great honour to a man, but such an honour in relation to a woman was exceptional and indicated a very special status of Tiy.

Genetic studies of the mummies closely related to Tutankhamun were conducted between 2008 and 2010. The analyses showed that the so called Younger Lady (KV35YL. Hawass et al. 2010, pp. 639-641) mummy is the mother of Tutankhamun. It also appears that Younger Lady is very closely related to the mummy from KV55, which is identified with Akhenaten (Hawass 2010, p. 641). The couple is considered to be cousins. Most importantly, Younger Lady is perhaps queen Nefertiti herself (Gabolde 2013, pp. 199-201). There is circumstantial evidence to confirm that. Firstly, Akhenaten could have decided to follow in the footsteps of his father and marry his cousin ${ }^{5}-$

\footnotetext{
${ }^{4}$ Satamon was a daughter of Amenhotep III and queen Tiye, so she was a sister of Akhenaten.

${ }^{5}$ According to DNA analyses, Yuya, the father of queen Tiye, was the uncle of Amenhotep III, so Tiye and Amnehotep III were cousins. The mother of Amenhotep III, Mutemwya (KV35A) was the sister of Yuya.
} 
according to the DNA studies of Younger Lady, her parents could be the siblings of Amenhotep III and Tiye (Gabolde 2013, pp. 194-196). Secondly, Marc Gabolde suggests that Tutankhamun could be the seventh child of Nefertiti and Akhenaten ${ }^{6}$. The boy could have been born when Maketaten died in the 13. or 14. year of the reign of Akhetaten. This hypothesis is confirmed by the reliefs from the Royal Tomb in Akhetaten. In Gamma Chamber, portrayed was the scene of the royal couple's lament over the death of their daughter, Maketaten. Just next to that portrayal, one can see a nanny with a small child in her arms. The baby is definitely a royal child - it is confirmed by a fan presented above the child. Most scholars assume that the child is a newly-born daughter of princes Maketaten, who died during childbirth. However, we do not have irrefutable evidence of this.

Nefertiti had a younger sister, Mutnodjemet, who resided at the royal court (Tyldesley 2006, p. 125). However, the word sn.t was used fairly freely, so Mutnodjemet could be a sister of the queen, but also a half-sister or a milk-sister. The woman is portrayed on reliefs in Amarna tombs, where she is often accompanied by three oldest princesses: Meritaten, Maketaten and Ankhesenpaaten. She disappeared before the birth of Neferneferuaten - we will not find her on any of the reliefs where there are four princesses portrayed on reliefs with two younger sisters, Neferneferure and Setepenre. Mutnodjemet disappeared from the court in Akhetaten. Most likely she married the future king of Egypt, Horemheb at this time (Brunner-Traut 1982, col. 519).

\section{TITULARY OF THE QUEEN}

The part of the name of Nefertiti, Nfr-nfr.w-jtn, means Beautiful is Beauty of Aten. This name appears in the Amarna texts before the husband of the queen, Amenhotep IV, changed his name to Akhenaten in Year 5 of his reign (Arnold 1996, p. 9).

The name of the queen is characterized by a very interesting way of writing the name of Aten, which is contained in the queen's name. The name of the god is facing frontally to the hieroglyphs that make up the name $N f r-n f r . w-j t n n f r . t-j j . t j$. It is visible thanks to the inverted reed (Tawfik 1973, pp. 82-83):

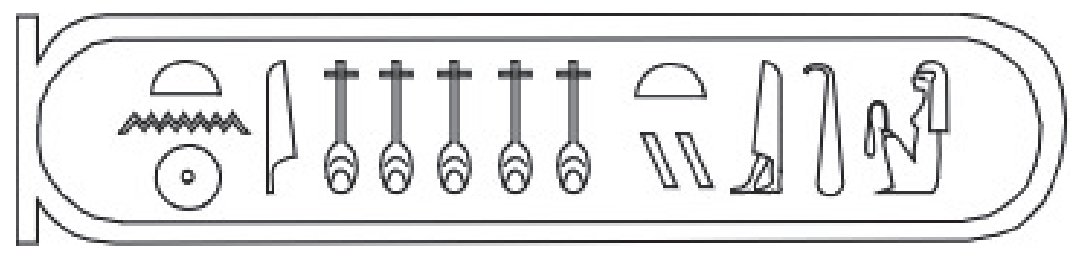

\footnotetext{
${ }^{6}$ More on this subject: Gabolde 2013, pp. 196-199.
} 
According to S. Tawfik, this inverted reed reflects the role of the queen in the cult of god, because on the reliefs Nefertiti is always facing Aten. Therefore, the hieroglyphs' role was also to remind us of this fact (Tawfik 1973, p. 86), even more that the full name of the ruler ends with a symbol of the seated queen wearing the crown with ureus and holding insignium of power in her hands (Gardiner 1957, p. 448$)^{7}$. Insignium was probably a little broom used to chase away the flies. According to Henry G. Fischer, the inverted name of the god in the cartouche of Nefertiti points out to the fact that Akhenaten is the main source of her contacts with god. The cartouche of the queen is shown most commonly together with the cartouches of the pharaoh, which are preceded by the cartouches of Aten (Fischer 1977, pp. 92-93, fig. 1). The hieroglyphs from the cartouches of the royal couple are directed to the names of the deity, while the hieroglyphs from the names of the Aten are turned to the cartouches of Akhenaten and Nefertiti.

The two names of Nefertiti were written in a single cartouche. However, in Thebes and Akhetaten the name of the queen is sometimes inscribed in two cartouches, which

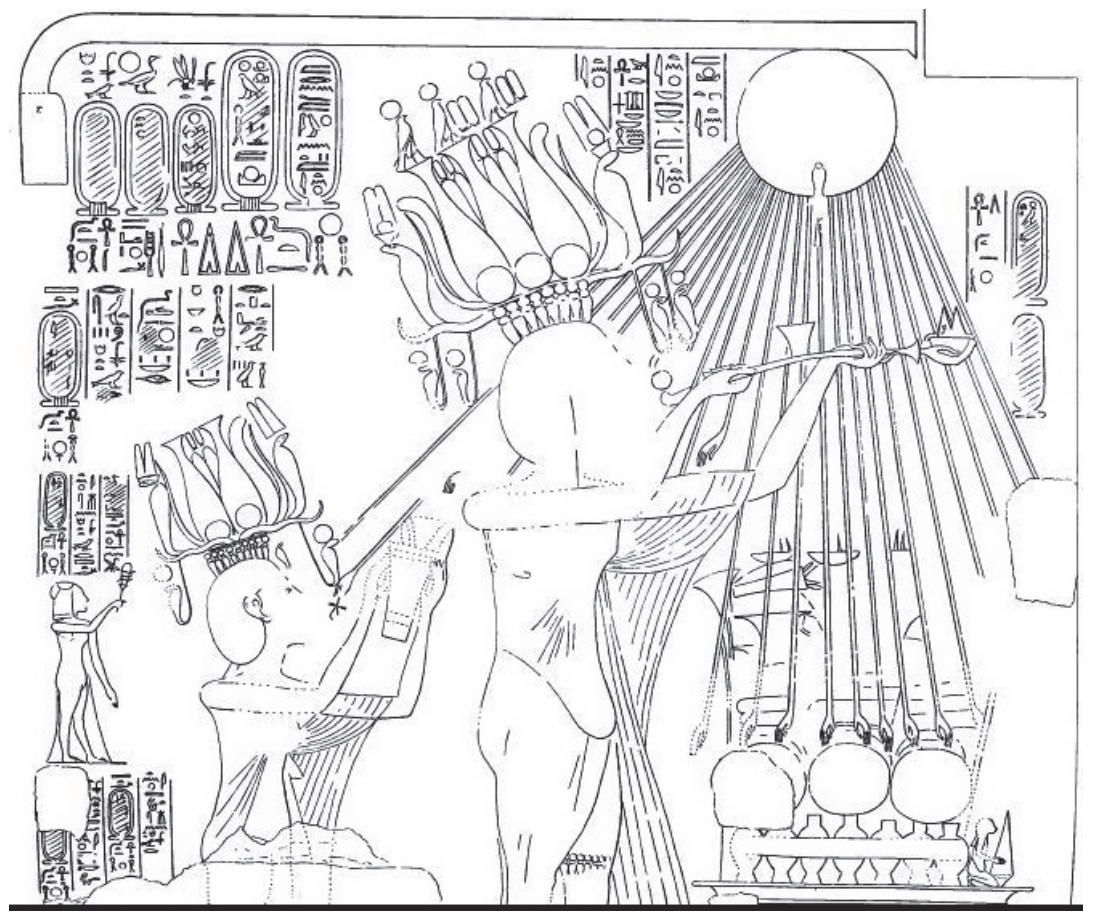

Fig. 1. Fragment of a relief in the Tomb of Panehesy (Davies, The Rock Tomb of Amarna, Part II, London 1905, tab. VII.)

\footnotetext{
${ }^{7}$ According to The List of Hieroglyphic Signs of A. Gardiner - B7.
} 


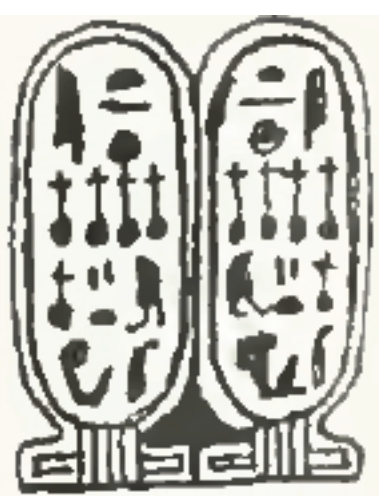

Fig. 2. Mould for Double Cartouche of Queen Nefertiti (MMA 21.9.188; Petrie, William M. F. Tell El-Amarna. Warminster, Wiltshire; Encino, California: Aris \& Philips, Malter, 1974, Pl. XV 82.)

makes it similar to the royal titulary (Tyldesley 2003, p. 73). There exists a pottery mold (fig. 2) of the double cartouche of queen Nefertiti (MMA 21.9.188), which was excavated at Tell el-Amarna by W. M. Flinders Petrie and Howard Carter during the 1891-1892 excavations (Petrie 1974, pl. XV, p. 82). As far as the form of Akhenaten or Aten's names are concerned, in every cartouche a different name (or its part) was written. In the case of Nefertiti, two names were written in each cartouche.

Nefertiti was presented as The Great Wife of the King but also The Lady of the Two Lands. These titles are indicative of her strong position in politics.

The relief at the entrance to the Amarna tomb of Api shows Nefertiti and Akhenaten offering the cartouches of the deity to Aten, also small figures of the queen and the king (Davies 1906, vol. IV, pl. XXXI). The queen was described there by the following phrase:

(j)r(j.t) p`t wr.t hs.wt nb.t jm3t hnnm.t rš wbn p3-jtn $r$ rdj.t n.s ḩs.wt htp.f $r q b$ mr.wt.s ḥm.t nswt wr.t mr.t.f ḥnwt šm $\mathrm{m}^{\complement}$ mḥw nb.t t3.wj (nfr-nfr.w-jtn nfr.t-jj.tj) 'nh.tj $\underline{d} t r-n h h$

- Hereditary princess, great of kindness, the lady of grace, united with joy, she, for which rises up the pa-Aten, to give her grace, and for which he falls to double the love to her, The Great Royal Wife, his beloved, The Lady of the South and the North. The Lady of the Two Lands (Nefer-neferu-AtenNefertiti)|, may she live forever and always.

Nefertiti carried the title of The High Priestess-Musician and she is The One, who makes that Aten rests through the sweetness of her voice and beautiful hands in which she keeps sistra (Jacq 2007, p. 113). 


\section{THE POLITICAL ROLE OF NEFERTITI}

Reliefs show us how high was the political as well as religious function performed by Nefertiti. According to the new canon of representations that portrayed Akhenaten, also Nefertiti had to be shown in accordance with Amarna art rules. The queen had received small shoulders, wide hips, thick thighs and rounded buttocks, which eloquently emphasized her fertility and the fact that she gave birth to six daughters. However, she retained a narrow waist. Abundant breasts did not characterize only women, so they were not emphasized in any special way. Nefertiti was usually presented in a delicate, almost transparent dress, that was tied with a sash at the waist or under the bust. The dress often completely revealed a naked body, because it was left open in the front (Tyldesley 2003, p. 113).

Nefertiti appears in scenes so far reserved only for the pharaoh, such as: the king in the chariot or the ruler killing enemies (Brunner-Traut 1982, col. 520). According to Earl L. Ertman, we have evidence to suggest that Nefertiti was Akhenaten's coregent for most of his reign (Ertman 1992, pp. 50-55).

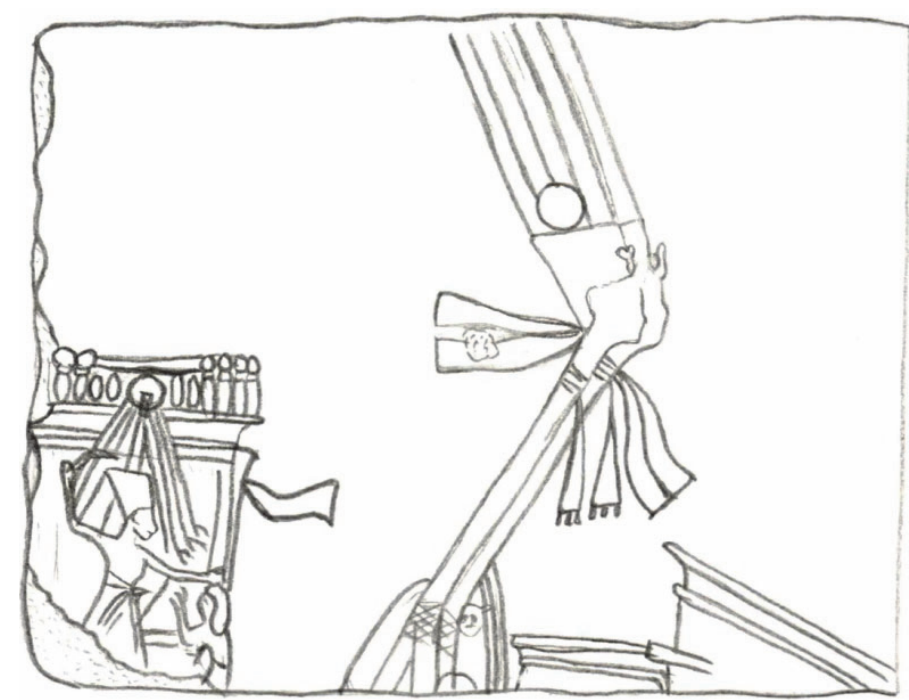

Fig. 3. Talatat from Hermopolis. The Museum of Fine Arts, Boston, 64.521 (drawing M. Kloska)

Scenes from talatat evidence a major political role of the queen. On the two of these blocks (fig. 3) discovered in Hermopolis (The Museum of Fine Arts, Boston, 64.521 and 63.260. Cooney 1965, pp. 82-85) we see two ships, one of which probably belongs to the queen. This may be indicated by the end of the oars showing the effigy of the queen who is represented in a characteristic flat top crown topped with 
two long feathers and a solar disc. The figure of Nefertiti was presented in the kiosk on the board of a ceremonial ship. The queen appears in the flat top crown. The representation is without precedent, because in one hand the ruler is pulling the captive's hair - the captive can be a woman. The other hand is used by the queen to massacre the captive with a sword khepesh. Scenes of this type ${ }^{8}$, as has already been mentioned, so far, as well as in later periods, were reserved only for the pharaohs who, by annihilating enemies, cleaned up the world to keep the divine law and order - maat. This scene may be compared to earlier representations of the queen Tiye, the wife of Amenhotep III, who is shown in the form of a sphinx trampling the enemies of Egypt (The Oriental Institute, 1980, pl. 49). Below this representation, on the second talatat another ship is represented, on which legs and the lower part of the torso are shown. Most likely they belong to Akhenaten, because in front of the figure we can see a kneeling prisoner.

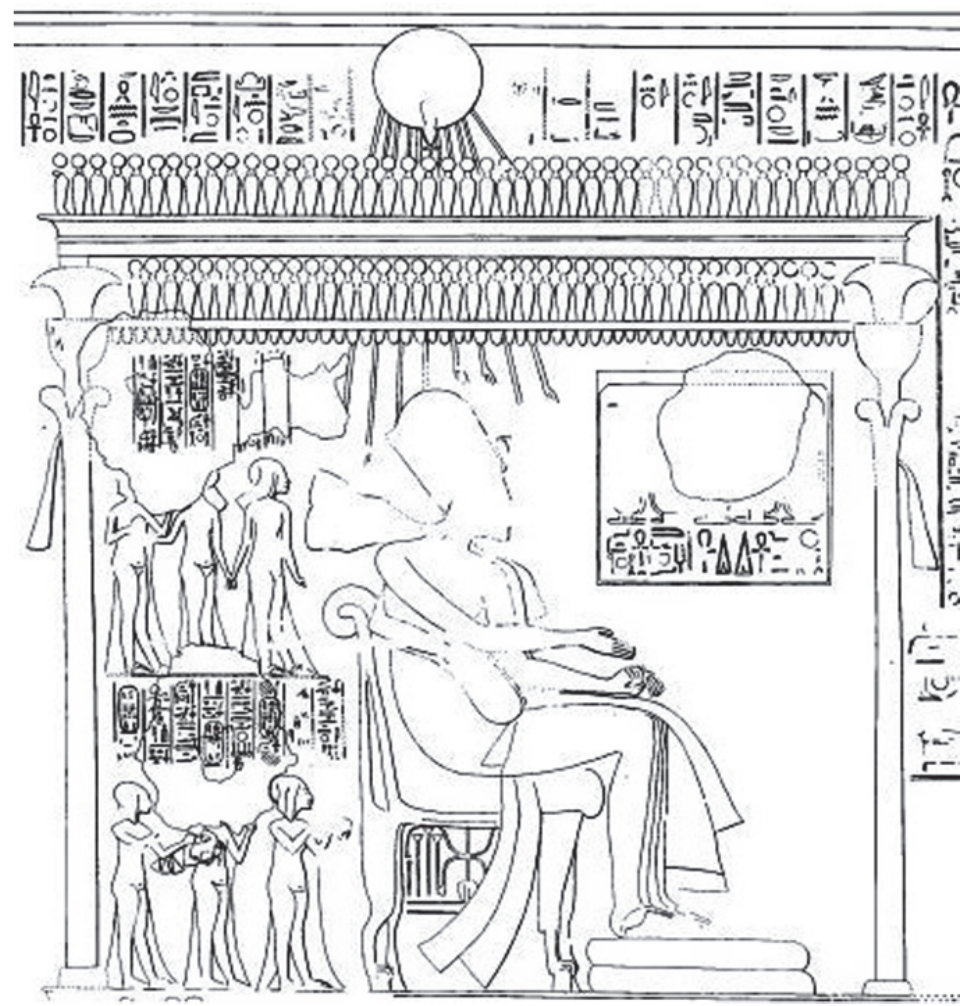

Fig. 4. The receiving scene of the tribute from Nubia and Syria. The fragment of a relief in the Tomb of Meryre (II). (Davies, The Rock Tomb of Amarna, Part II, London 1905, tab. XXXVIII.)

\footnotetext{
${ }^{8}$ More about the scenes of killing enemies during the Amarna Period: Ertman, 2006, pp. 59-65.
} 
In Amarna tombs of Panehesy (Davies 1905, vol II, pl. XIII, XVI), Mahu (Davies 1906, vol. IV, pl. XX, XXII), Ahmes (Davies 1905, vol. III, pl. XXXIIa) and Meryre (I) (Davies 1903, vol. I, pl. X) Nefertiti is represented in the chariot. The queen is usually portrayed standing next to Akhenaten and holding the reins with him. However, in the tomb of Panehesy, the royal couple was shown in two separate chariots and each spouse drives his or her own chariot.

Further evidence to confirms a high position of the queen is found in political scenes, in which Nefertiti is always represented with Akhenaten. In the Amarna tombs of Meryre II and Huya there are reliefs that show scenes of the tribute from Nubia and Syria in Year 12 of Akhenaten's reign, eight day of the second month of the winter season. It is the only event that we can see on the walls of the tombs which is dated so precisely. The royal couple is shown together. The queen and the king are portrayed in the same scale. In the tomb of Meryre II (fig. 4), Nefertiti was represented sitting on the throne next to Akhenaten. We can see her only as an outline. Behind the royal couple there are all princesses: Meritaten, Maketaten, Ankhsenpaaten, Neferneferuaten, Neferneferure and Setepenre (Davies 1905, vol. II, pl. XXXVIII). In the tomb of Huya (fig. 5. Davies 1905, vol. III, pl. XIII), there is a relief that shows the queen and the king in the golden palanquin, receiving tribute from Nubia and Syria. Akhenaten was represented in a rigid pose, holding the scepters of heqa and nekhakha in his hands.

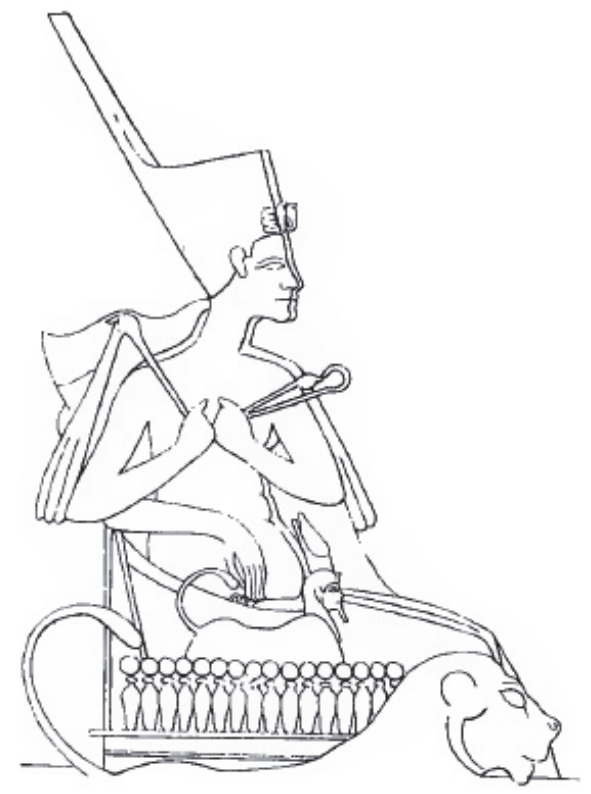

Fig. 5. The royal couple during the tribute by Nubia and Syria. The fragment of a relief in the Tomb of Huya (Davies, The Rock Tomb of Amarna, Part III, London 1905, tab. XIII.) 
The high political rank of Nefertiti is manifested by details present on the reliefs. A good example is the throne, on which the queen is sitting, shown on the stele from the altar at Akhetaten (Berlin, SMPK, Ägyptisches Museum, 14145). The royal couple was immortalized together with three elder daughters: Meritaten is held by her father in his arms, Maketaten and Ankhsenpaaten accompany the queen. Nefertiti and her husband, in robes and crowns characteristic for them, are sitting on thrones with their feet kept on the footrests. They are represented in the same scale. However, on other reliefs, the height of the queen's figure differs. Nefertiti can be equal to her husband or much shorter than him. However, it seems that not so much political factors but artistic factors influenced the scale of representation - figures showed on the reliefs are getting smaller and comprise a harmonious whole with the slanting rays of the Aten. Besides, it is worth noting that the pharaoh and his wife had already been shown in the same scale in earlier times. The statues of Hatshepsut and Thutmose II or Tiye and Amenhotep III provide a good example. On the stele, the god Aten takes care of the royal family. Deity surrounds the family with lifegiving rays and gives two ankh to the spouses. Very important are the thrones of the royal couple. The throne of the pharaoh is extremely simple in comparison to the queen's throne, which is decorated with the symbol of sema-taui ${ }^{9}$.

Another very important detail may be the headgear worn by Nefertiti. The queen can be seen in her characteristic flat top blue crown, a headscarf khat, a Nubian wig, a blue cap and in the crown shuty, crown hemhemet, but also most likely in a double crown of Egypt-sekhemty (cf. infra. Manniche 2010, p. 93).

The blue crown of Nefertiti, known from the Berlin's bust, is a high and flat cut headgear decorated with golden ribbons, whose red, green and blue insets correspond with the necklace worn by the queen. The crown probably derived from the god Amun, or was an elongated version of his crown (Collier 1996, pp. 97, 273). This type of headgear worn by the queen can be found on a relief in the Amarna Royal Tomb, in the so-called chamber alpha (Martin 1974, vol. 2, fig. 3, pl. 34). In this chamber Nefertiti is represented in the crown (fig. 6), which is decorated with a seshed band with two uraei, uraeus, cow horns with a sun disc and a ribbon (Collier 1996, p. 274). The solar disc is surrounded by cow horns, which were related to the cult of Hathor and Maat (Martin 1974, vol. 2, p. 31).

Nefertiti was also portrayed in a fitted blue cap crown (Collier 1996, p. 272), which is sometimes confused with a blue crown of the pharaohs. This type of headgear was usually worn without a wig.

On the relief of dignitary Panehesy in the Amarna tomb (Davies 1905, vol. II, pl. VII), both Akhenaten and Nefertiti wear large, richly decorated crowns hemhemet

\footnotetext{
${ }^{9}$ This motif means the union of two lands - Upper and Lower Egypt. The symbol sema-taui shows heraldic plants of the valley and the delta of the Nile, lily and papyrus, tied around the hieroglyph smA, which means unite.
} 


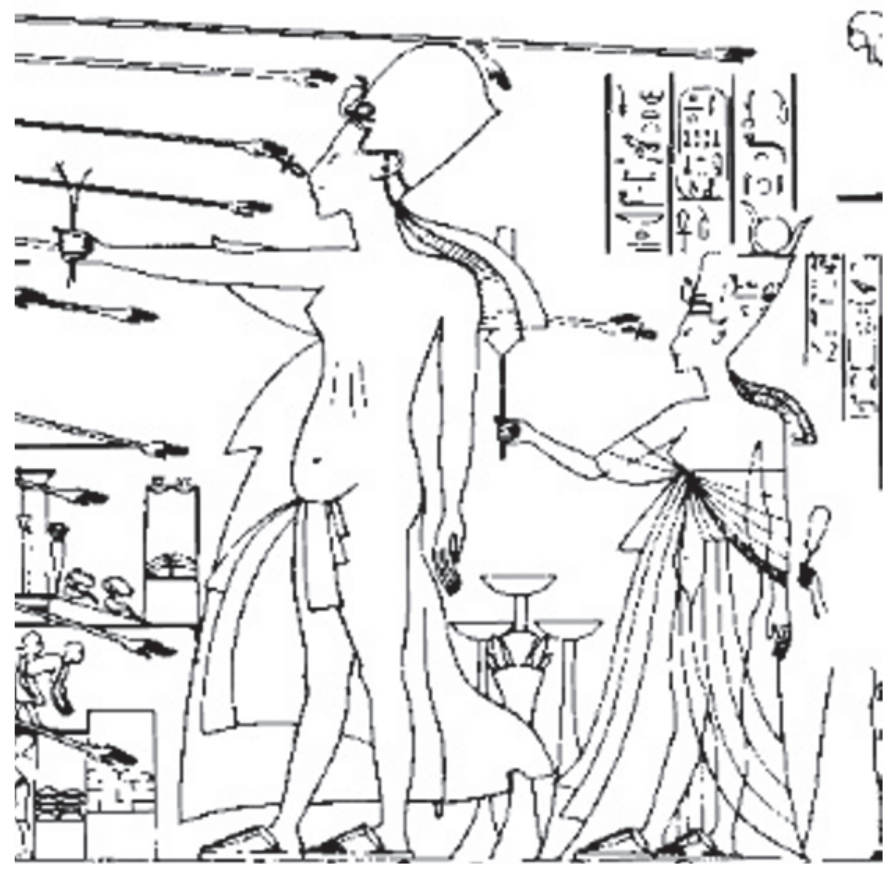

Fig. 6. The fragment of a relief in the Royal Tomb (Martin G.T., The Royal Tomb at El-Amarna, vol. 2, London 1974, Fig. 3.)

with small falcons ${ }^{10}$ (fig. 1), which are the incarnation of god Aten and his royal cartouches. It is the earliest and the most unusual presentation of this type of the crown. The classic hemhemet reminds three atef crowns joined together and worn on another headgear, e.g. a headscarf khat. The Nefertiti's crown represented on the relief is smaller than Akhenaten's crown and it looks as if only two atef crowns were joined together.

In the crown shuty with double feathers decorated with a solar disc, the queen can be seen among others on the sarcophagus of Akhenaten ( $c f$. infra).

Nefertiti was also portrayed in a Nubian wig, which was worn so far only by men (Tyldesley 2003, p. 155). Nefertiti and a second wife of Akhenaten, Kiya, were the ones to introduce this new fashion.

The queen was often portrayed in the khat headdress, which was reserved for pharaohs. However, the khat was also worn by queen Tiye and the goddesses Isis and Nephthys (Tyldesley, 2003, p. 155). On the previously mentioned representation from the tomb of Panehesy (fig. 1), where the royal couple have hemhemet crowns on their heads, Nefertiti also has khat on her head, while her husband most likely

\footnotetext{
${ }^{10}$ Probably small falcons are incarnations of the god Aten.
} 
wears the nemes. Sandra A. Collier believes that this is the representation without precedent because both types of headgear are shown on one relief, and a closer comparison shows that khat worn by the queen is a secondary variant of the royal nemes (Collier 1996, p. 87). It is worth noting that the king wearing the nemes is a representation of a living king who is identified with the god Re. On the other hand, a pharaoh in the khat headgear is supposed to symbolize the royal $k a$ or the dead king. This connects him to the god Osiris. We can refer this fact to the abovementioned representation, then Akhenaten will symbolise a living ruler and Nefertiti will symbolize the royal $k a($ ?). It is noteworthy that Akhenaten was the king to have been most often represented in the chat headdress, perhaps because he identified himself most with his $k a$ (Collier 1996, pp. 90-91).

\section{THE RELIGIOUS ROLE OF NEFERTITI}

Akhenaten celebrated heb-sed in Year 2 or Year 3 of his reign (Reeves 2001, pp. 96-97). To mark this anniversary, he built solar temples dedicated to Aten. To the east of the temple complex in Karnak Gem-pa-Aten temple was built, The Aten was found, and adhered to it the Hut-Benben temple, Mansion of the Benben-stone (Reeves 2001, pp. 94-95). The temples were destroyed in ancient times by the successors of Akhenaten. However, talatat, the sandstone blocks covered with reliefs and paintings, which survived from Hut-Benben, show Nefertiti in the king's role of priestess in the company of her eldest daughter. Meritaten was represented in the way typical of the Egyptian Great Wife of the King. But the real queen was Nefertiti and only in the absence of her husband she took the role of the ruler; to complete the ritual, she needed a companion (Tyldesley 2006, p. 130).

On the reconstruction of the pylon from Hut-Benben we can see Nefertiti together with Meritaten offering sacrifices to Aten. The queen is rising her arms to god. She is dressed in her characteristic ethereal, pleated dress tied under the breasts. On her head, she is wearing a tripartite wig and a crown with double feathers and an uraeus. The princess is represented in a smaller scale, standing behind the mother and holding a small sistrum in her hand. She is wearing the so-called curl of youth (Redford 1987, p. 76). The scene was represented twice (we see the figures of Nefertiti and Meritaten facing each other). Talatat was also recovered from the second pylon of the Great Temple in Karnak. These sandstone blocks in ancient times created the socalled Nefertiti's colonnade ${ }^{11}$, which was partly reconstructed. On the pillars represented were similar scenes as the ones on the pylon of the Hut-Benben temple - the queen together with Meritaten are holding sistra in their hands ${ }^{12}$ and honouring

\footnotetext{
${ }^{11}$ More about Nefertiti's Pillars: Loeben, 1994, pp. 41-45.

${ }^{12}$ More about the role of sistrum in Amarna Period: Vosburg 2011.
} 
the Aten. This time Nefertiti is wearing a wig decorated with uraeus (Redford 1987, p. 77) on her head. According to Lise Manniche, the hathoric sistrum, with which Nefertiti and princesses were portrayed, can symbolize the continuity of the conception of world creation. Despite the introduction of new religious concepts, the relationship between the goddess Hathor and the god Re remained unchanged. L. Manniche believes that the Nefertiti's colonnade presents the queen as Hathor in front of Aten (Manniche 2010, pp. 13-26).

Until 1976, the researchers calculated that on the sandstone blocks from HutBenben the name of Nefertiti was used 564 times, while Akhenaten only 329 times. It is worth citing other surprising numbers: the name of the queen appeared 67 times on the offering table, and the name of the pharaoh only 3 times. In 13 cases the names of the royal couple were appeared together (Tyldesley 2003, pp. 66-67). Stone blocks, which were used to conduct these analyses, mostly came from HutBenben, where the queen played the most important role. This is excellent evidence confirming the dominance of Nefertiti in the range of functions formerly performed only by the pharaoh.

The temple Hut-Benben was demolished during the reign of the successor of Tutankhamun, Horemheb. The part of talatat forming the Nefertiti's colonnade was bricked up as already mentioned in the II pylon of the Great Temple in Karnak. It should be noted that blocks with representations of the queen were bricked up in a very careful and non-random way. This phenomenon was first noticed by a French researcher, Henri Chavrier, who worked on the II pylon in the late 1940s. It turned out that talatat were reconstructed in such a way that one could restore the scenes representing Nefertiti. However, a few scenes, probably intentionally, were shown upside down. The figures of the queen, which were carefully bricked up in the pylon, often have disfigured faces and hands, which end the rays of the god Aten, have cut fingers. Actions of Horemheb's workers were most likely non-accidental. Maybe it was a kind of a symbolic ritual, damnatio memoriae - an act of revenge, for establishing the cult of god Aton by Akhenaten. It is likely that the destroyed hands of the deity were never to surround the queen with love and keep her safe (Tyldesley 2003, pp. 68-69). What could be the reasons for that? It is possible that the answer lies in politics, such as the usurpation of the throne of Egypt or Horemheb's personal aversion to Nefertiti.

\section{NEFERTITI IN THE DIMENSION OF THE SACRED}

A very important issue is the presentation of Nefertiti in the dimension of the sacred because probably, despite the fact that she performed high religious and political functions, she was also deified. 
The role of Aten as the god of fertility remained in the sphere of theory. The god, deprived of the anthropomorphic figure, did not have a wife and a child, with whom he could create a traditional triad in Egyptian theology, similar to Osiris, Isis and Horus or Amun, Mut and Khonsu. However, Akhenaten used traditional ideas and ordered to represent the god together with the royal couple, thus creating a divine triad ${ }^{13}$. Aten was identified as the creator with the god Atum, Akhenaten performed the role of Atum's child - Shu and Nefertiti was shown in the role of the twin sister of Shu - Tefnut. The representations of the six daughters of Akhenaten and Nefertiti, besides being the confirmation of the spouses' fertility, also performed an important religious function - they replaced other six gods of Ennead: Geb and Nut, Osiris and Isis, Seth and Nephthys. The girls together with their parents and the god Aten created the divine Ennead just like the model of the nine gods from Heliopolis (Reeves 2001, p. 146).

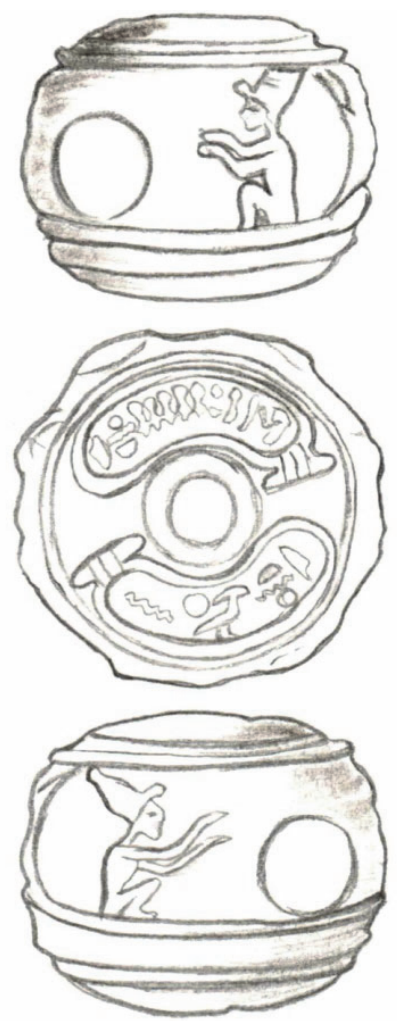

Fig. 7. The faience bead with the representation of the royal couple as the god Shu and the goddess Tefnut. Kopenhagen, Ny Carlsberg Glyptotek (drawing M. Kloska)

\footnotetext{
${ }^{13}$ More about Amarna triad: Bayer and Eaton-Krauss 2012, pp. 21-41.
} 
The visual confirmation of the idea of Akhenaten and Nefertiti as Shu and Tefnut is the faience bead, now stored in Copenhagen (Ny Carlsberg Glyptotek, AIN 1791; fig. 7). The royal couple was represented as a pair of deities, Shu and Tefnut, sitting on a bark and worshipping the solar disc (Reeves 2001, pp. 165-166) with their raised hands. In the opinion of Nicholas Reeves, the blue bead was probably a royal gift to one of the royal officials.

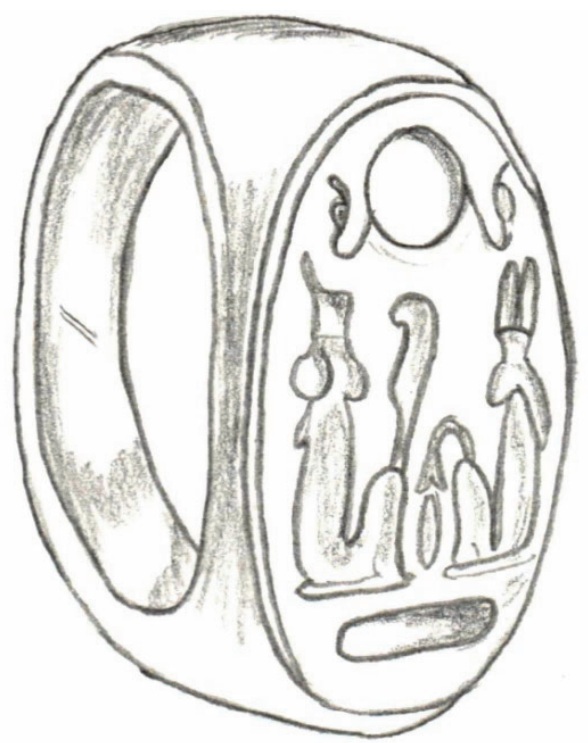

Fig. 8. The gold ring with the representation of the royal couple as the god Shu and the goddess Tefnut. Cairo, Egyptian Museum (drawing M. Kloska)

The gold ring, which is now located in the Cairo Museum, shows also the royal couple, that symbolizes the children of the sun god - Shu and Tefnut (Tyldesley 2006, p. 131, fig. 8). Akhenaten is represented in a red crown holding the feather of Maat in his hands, whereas Nefertiti is shown in a double feather crown holding the insignium of power in the form of withered royal lily (Tyldesley 2003, p. 60). Aten rises above the couple. Aten is depicted as a disc surrounded by two uraei. Under the king and queen's feet the symbol of the earth $\mathrm{tA}^{14}$ is shown.

Another evidence supporting the deification of the queen is the so-called asexual colossus from Karnak (perhaps there were more such monuments), which is identified as a representation of Nefertiti (Manniche 2010, pp. 54-57, 93). The queen has to reflect, also in this case, the goddess Tefnut. Then, she would complement the

\footnotetext{
${ }^{14}$ According to A. Gardiner's Sign List N16.
} 
colossuses of Akhenaten, which is the personification of the twin brother of the goddess, Shu. Nefertiti was probably shown in one of the Egyptian crowns - in the sekhemty crown, the so-called Double Crown. Until recently, the statue was considered a colossus of Akhenaten, which according to M. Pillet and W. Westendorf identified himself as a divine, sexless creature (Manniche 2010, p. 86). Only a pra-god could be androgynous. Lise Manniche puts the following arguments in favour of the theory that the colossus shows the queen: primarily the female body, no names of Akhenaten, a secondary beard, the damage to the face and the fact that the queen was also shown in the form of other colossi of Karnak. The only argument which for some researchers may dismiss this hypothesis is the fact that we do not know other representations of Nefertiti in the double crown (Manniche 2010, pp. 93-94).

In Karnak, fragments of another colossus were also discovered. This colossus is also believed to be a representation of the queen. Excavations in the so-called Temple $A$ in the north-east of the Mut enclousure in Karnak produced the base of the colossal statue. This base probably originally decorated the Gem-pa-Aten temple. It has been estimated that the colossus, which was made of pink granite, was once $4.5 \mathrm{~m}$ high. On its base, which was reused after turning it upside down, are three pairs of feet - one large and two smaller ones (Van Dijk 2008, pp. 246-261). According to Jacobus Van Dijk, the statue was made before the capital was moved to Akhetaten and, most importantly, a statue represented Nefertiti with her two eldest daughters, Meritaten and Maketaten (Van Dijk 2008, pp. 248-250).

In Karnak, erected also was an avenue of sphinxes, which originally led to the Gem-pa-Aten temple. Part of the sphinxes had the face of Akhenaten and the other part bore the face of his wife. The Pharaoh's sphinxes were shown with royal beards and the nemes headgear on their heads, while those belonging to Nefertiti had wigs. The sphinxes were of the same size, which is quite unique because it proves the equality of the royal couple (Blyth 2006, pp. 117, 124). This example perfectly illustrates the inseparability of Akhenaten and Nefertiti and shows how the royal couple complements each other while performing the divine power that was entrusted in them by Aten (Jacq 2007, p. 54). After the death of Akhenaten, sphinxes were moved from the temple of Aten to the southern Karnak probably by Akhenaten's son Tutankhamun. After that, the royal faces were transformed in the heads of rams. The newly created criosphinxes decorated the processional avenue which was dedicated to the god Amun (Blyth 2006, p. 117).

The next important argument, confirming Nefertiti's divine status, is the sarcophagus of Akhenaten. The sarcophagus was made of polished pink granite. Its fragments were discovered in the Royal Tomb in Akhetaten (Martin 1974, vol. 1, pp. 13-17, pp. 6-9). The reconstruction has helped to establish the decorative program of the object. On the four sides of the sarcophagus we can see Aten. His rays were probably to ensure the safety of the deceased pharaoh. At each corner, there is Nefertiti with spread arms, embracing and protecting the body of the pharaoh. The 


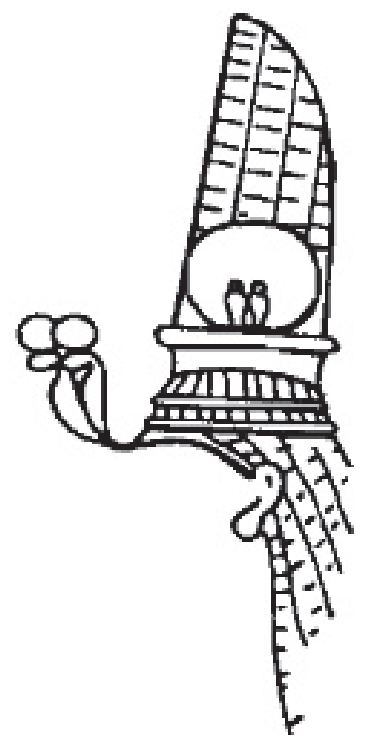

Fig. 9. The outline of Nefertiti's crown from the sarcophagus of Akhenaten (Martin G.T., The Royal Tomb at El-Amarna, vol. 1, London 1974, p. 15.)

women shown at the corners do not resemble the queen's representations, which are known from other artefacts from the Amarna Period. The figures shown on the sarcophagus were made by an unskilled person, but thanks to the cartouches we can be sure that the portrayed person is Nefertiti. The queen is wearing a long wig decorated with a double uraeus and a high crown consisting of a solar disc decorated with two cobras and two high feathers (fig. 9). Over every Nefertiti's image rises up the god Aten. Nefertiti represents the four protective goddesses: Isis, Nephthys, Neith and Selket. In fact, the tradition of decorating sarcophagi with the images of the goddesses started from Nefertiti. The sarcophagus of the son of Akhenaten, Tutankhamun, is protected by the abovementioned goddesses, but we do not know any such decorated sarcophagi from before the Amarna Period. Akhenaten's successors probably took the idea of decorating the sarcophagi from the canopic chests of their predecessors, e. g. Amenhotep II (Dodson and Ikram 1998, p. 282) ${ }^{15}$. According to the myth of Osiris, Isis and Nephthys protected the dead Osiris. Neith and Selket were artificially added, so that the goddesses could create together the equivalent of the four sons of Horus, whose representations decorated the canopic vases. Can we, thus, assume that Akhenaten also wanted his body to be protected by goddesses after his death? Can Nefertiti be considered to be a goddess?

${ }^{15}$ The canopic chest of Amenhotep II for the first time was decorated with four goddesses with arms spread wide in the act of protection. 


\section{THE DISAPPEARANCE OF NEFERTITI - THE QUEEN AS A COREGENT AND A SUCCESSOR?}

The latest representation of the whole royal family is a relief from the Amarna tomb of Meryre. The scene shows the tribute paid by the Syrians and Nubians in the 12 Year of Akhenaten's reign (fig. 4), which has already been mentioned above. Most probably during this event, the plague, which spread in the Middle East at that time, was brought to Egypt. In no time, the disease took the heaviest toll at the royal court. Researchers estimate that in 13 or 14 Year of Akhenaten's reign princes Meketaten died. Her body was laid in the Royal Tomb at Amarna (Seyfried 2012, pp. 190). On one of the reliefs decorating the burial chamber, the royal couple is shown grieving their daughter, who is portrayed resting on the bier. At the same time other female members of the royal family: Tiye, Kiya and three other princesses - Neferneferuaten, Neferneferure and Setepenre (Tyldesley 2003, pp. 162-163) disappeared. One may suppose that they also died as a result of the epidemic.

Until recently, it was thought that Nefertiti was also a victim of the plague and left the world of the living soon after the death of Meketaten. However, if that had been the case, her body would probably also have rested in the Royal Tomb and at least this event would have been registered on one of the reliefs, as it happened in the case of Maketaten's death. One can suspect that Akhenaten would want to commemorate the loss of his beloved queen. Only one piece of evidence - a fragmentary preserved ushebti, reconstructed by Christian Loeben (Loeben 1986, pp. 99-107) can confirm the preparation for the burial of Nefertiti.

According to another hypothesis, the queen was banished because of a terrible act that she committed. She was supposed to have been divorced and closed in the North Palace in Akhetaten (Tyldesley 2003, p. 165). For this reason, her name in Maru-aten was to be replaced by craftsmen into the name of Meritaten. But today we know that it was the name and images of queen Kiya, not Nefertiti, which were removed from the temple.

If Nefertiti was not banished, according to some Egyptologists, such as John R. Harris and Julia Samson (Samson 1977, p. 88), the queen became the coregent of Akhenaten and she adopted the names of Ankhkheperure Neferneferuaton. After the death of her husband, she took over the rule under the names Ankhkheperure Semenkhkare (Van der Perre 2012, p. 196). A few years later she passed the Egyptian crown to young Tutankhamun (Tyldesley 2003, pp. 166-167).

There are several other hypotheses ${ }^{16}$ about the last years of Nefertiti's life, One states that Akhenaten backed down and sent his new coregent, Semenkhkare, to the priests of Amun in order to ask for forgiveness. It is said that the pharaoh fell in love

\footnotetext{
${ }^{16}$ More on the theories about the disappearance of the queen: Theis 2010, pp. 14-19.
} 
with his new companion. This feeling was supposed to be equal to the love for Nefertiti. The queen learned of her husband's scheming and decided to take revenge on Semenkhkare and murdered him (Jacq 2007, p. 170). However, this and other theories are unconfirmed by either archaeological or historical sources and are pure fantasy.

Currently, we can definitely reject the hypothesis that Nefertiti died shortly after the death of Maketaten, because the recent discovery of the Dair al-Barsha-Project sheds a new light on the mysterious disappearance of the queen. In the great Wadi Dayr Abu Hinnis, on one of the rock pillars, eight meters above the ground, a text written in a raddle was discovered, which provided new information about the queen. The inscription is dated to the fifteenth day of the third month of the flooding season in the 16 Year of Akhenaten's reign. Most importantly, in the third line of the text we can read the Great Wife of the King, his beloved, The Lady of Two Lands, Nefertiti Neferneferuaten (Van der Perre 2012, p. 197). This only confirms that the queen was still alive and was still the main queen in the 16 Year of her husband's reign. The text does not mention any coregent, but this does not prove that in the last year of his reign Akhenaten could not have had a co-ruler in a male or female form of pharaoh Semenkhkare.

The theory, according to which Nefertiti would initially be a co-ruler and after Akhenaten's death would take the Egyptian throne, may be supported by an analysis of the preserved steles. The stele of the soldier called Pasi (Berlin State Museums, Ägyptisches Museum und Papyrussammlung, 17.813) represents Aten, who shines on two figures sitting on the thrones. According to the first hypothesis, the scene shows Akhenaten in a double crown, who turns his face to the person behind him wearing blue crown and touches this person's chin. The second person is young Semenkhkare, who has his arms around Akhenaten. This scene prompted speculation about the homosexuality of Akhenaten. The relief may, however, show Akhenaten together with Amenhotep III - in this case, the stele could evidence the fatherson coregency (Tyldesley 2003, p. 167). According to another theory, Akhenaten was presented with his wife, Nefertiti (Reeves 2001, p. 167), who could function as a co-ruler and after the death of the pharaoh, could become a ruler as Semenkhkare. Cartouches carved on the stele are essential in making the determination. Two pairs surrounded the solar disc, and three were carved on the right side. Cartouches were never inscribed. We can guess that double cartouches flanking Aten were intended for his two names. The remaining three cartouches point to the fact that the craftsmen were supposed to write the names of the royal couple in them: two cartouches were left for Akhenaten and one for Nefertiti (Reeves, 2001, p. 168).

There exists one more unfinished stele (Berlin State Museums, Ägyptisches Museum und Papyrussammlung, 25574) showing two people who are looked after by Aten. Both figures are standing in front of the sacrificial table and holding the scepter $a b a$ in their hands. The first person in a wig on his head is probably Akhena- 
ten, while the second figure in the characteristic flat top crown should be identified as Nefertiti. Once again, the most important are cartouches, despite the fact that they remain empty. Next to Aten, three cartouches were carved, which would indicate the possibility of inscribing in them the king and queen's names. However, between the last cartouche and the solar disc we can see a small, shrunken and clumsily placed cartouche. One can only guess that this cartouche was carved later. Four cartouches may indicate the changes, which took place at the Amarna court and can be identified as the pharaoh and his coregent (Reeves 2001, p. 169). As a result, this stele may be the missing piece of the history of the Amarna Period and explain the mystery of Nefertiti's co-regency with Akhenaten.

An additional argument supporting the theory that Nefertiti acted as the coregent of Akhenaten under a different name is present in the eyes of several faience rings (Petrie 1974, pl. XV), discovered by W. M. Flinders Petrie during the excavations in Tell el-Amarna in years 1891-1892. On several artefacts, the name Ankhkheperure was written in the feminine form by adding the ending $t$ which gave the name Ankhetkheperure. Below, there is an added epithet, which expresses the dependence on the currently reigning king $m r . t W^{\complement}-n-R^{\top}-$ beloved Akhenaten.

Today, we can distinguish two main theories dealing with Amarna succession ${ }^{17}$. According to the first one, what happened was the co-regency of Akhenaten and Anchcheperure Neferneferuaton. After the death of Akhenaten, his coregent stepped down from the throne and Anchcheperure Semenkhkare took over. One may wonder why there is no mention in the Amarna Letters of the second ruler. James P. Allen believes that the division of power was purely practical. Akhenaten was responsible for foreign affairs and ruled in Akhetaten, whereas Nefertiti was responsible for the rest of Egypt ${ }^{18}$. The second theory assumes that Anchcheperure Semenchakare was supposed to be the successor of Akhenaten. This is why he married Meritaten. He ruled in Egypt together with his father-in-law (Allen 2009, p. 20) ${ }^{19}$ but died before Akhenaten or shortly after him. Due to the fact that Tutankhamun ${ }^{20}$ was still too young to claim the throne, Nefertiti started to rule Egypt as Anchcheperure Neferneferuaton, as the regent of her young stepson (Tyldesley 2003, p. 178). It is interesting why Meritaten was not chosen as a regent and why Nefertiti adopted her

\footnotetext{
${ }^{17}$ More of this subject in: Allen 2009, pp. 9-20.

${ }^{18}$ More potential evidences supporting to the coregency of Nefertiti and Akhenaten, and the existence of the male ruler between governments Akhenaten and Tutankhamun in: Allen 1994, pp. 7-17.

${ }^{19}$ According to J.P. Allen Semenkhkare was the younger brother of Akhenaten, who was the son of Amenhotep III and Tiye. While Tutankhamun was his son, who, like his father, married the one of Amarna princesses - Anchesenpaaton.

${ }^{20}$ Tutankhamun and Smenkhkare is sometimes regarded as brothers. Their parents would be Amenhotep III and Satamun or Akhenaten and Kiya. More of this subject in: Tyldesley 2003, pp. $174-175$.
} 
own throne name as a regent ${ }^{21}$. Could the queen's intention was to take over the country and the change of her name was the first step?

It is worth mentioning that we now have the archaeological evidence of the existence of the ephemeral Ankhkheperure. Recent research in Tell el-Borg, in the northern Sinai, led to the discovery of fragments of non-inscribed reliefs, which, according to Earl L. Ertmana and James K. Hoffmeier, portray king Ankhkheperure. Researchers believe that the style of representation does not indicate either the Akhenaten or Tutankhamun. The identification of pharaoh Ankhkheperure was confirmed by two vine containers, discovered in Tell el-Borg, bearing the name of the pharaoh (Ertman and Hoffmeier 2008, pp. 296-302).

Noteworthy is one more important issue related to Meritaten. According to the supporters of the theory that the queen ruled together with her husband, Nefertiti needed her own queen to perform both religious and political functions. Meritaten could become this queen. What happened to Akhenaten then? The Pharaoh could not remain without a partner, so Meritaten could perform the function of the queen with regard to both parents - mother and father, or Anchesenpaaton became the queen of Akhenaten (Tyldesley 2003, pp. 187-188).

According to James P. Allen, Nefertiti not necessarily must have been the female coregent of Akhenaten, because her name Neferneferuaton was also the name of the fourth daughter of the royal couple, Neferneferuaton Younger (Allen 2009, pp. 18-19). According to the calculations in the 16 or 17 Year of Akhenaten's reign, the princess was about 13 years old.

\section{CONCLUSIONS}

Nefertiti certainly was not an ordinary queen. On the reliefs from Thebes and Amarna, Nefertiti performed the functions that were originally reserved only for the ruler. She was portrayed with a club in her hand in order to control the chaos. She was shown driving the chariot alone and attributes of the supreme power were represented next to her. In the religious sphere, she was also equal to her husband: she celebrated rituals, offered sacrifices to the solar god, played the role of goddess Tefnut and protected the body of Akhenaten placed in a sarcophagus. The question whether her status was definitely equal to the pharaoh's and whether she was deified remains open.

Despite the fact that the queen took an active part in state ceremonies, received the tribute together with Akhenaten, destroyed the enemies of Egypt, drove her own chariot, and was portrayed in the tombs in Akhetaten giving gold to dignitaries, we

\footnotetext{
${ }^{21}$ More of this subject in: Dodson 2009, pp. 41-49.
} 
must beware of drawing hasty conclusions about her position. It is undeniable that the queen took over some of the functions that had previously been reserved for the pharaoh, but she never claims to be the king. While represented with Akhenaten, Nefertiti serves as a devoted wife, with the king usually acting as the dominant figure in these portrayals.

Did Nefertiti play the role of the co-ruler? We do not have enough archaeological or historical evidence to clearly and definitely answer this question. Still, we cannot contradict or reject the thesis of the co-regency between Akhenaten and Nefertiti in the last years of the pharaoh's reign. The dual kingship of royal couples is possible as well as the takeover of the Egyptian throne by the queen after the death of her husband.

Was Nefertiti the goddess? The deification of the royal wife was nothing out of ordinary. Ahmose-Nefertari, the wife of the first pharaoh of the XVIII dynasty, Ahmose, together with her son, Amenhotep I, were considered as a protective deity of the Theban necropolis. This happened many years after her death, at the time of the XIX dynasty. Ahmose-Nefertari was particularly worshipped at Deir el-Medina (Schlögl 2009, p. 155), yet, admiteddly, she did not receive this status during her lifetime.

Nefertiti played a role of the goddess Tefnut. She was the female complement of the divine triad. The queen as the goddess Tefnut complemented Akhenaten, who was identified with the god Shu. Nefertiti protected the body of her dead husband. Can all this be perceived as a clear proof of her deification? Nobody could ensure Akhenaten's safety but the god Aten and the beloved wife of the pharaoh, Nefertiti. While drawing the conclusions, we should remember not to look at ancient Egypt through the prism of the present, where we deal with clear boundaries between what is divine and what is human. Ancient Egyptians did not have such sharp distinction between sacrum and profanum, and the concept of divinity was not clearly defined. Nefertiti was worshipped, because this was part of Aten's cult. The queen was the female element and she embodied the aspect of fertility.

Until recently, Egyptologists were convinced that Nefertiti died or at least retreated into the shadows of the Amarna court shortly after the death of Maketaten. However, thanks to the recent discoveries of Dair al-Barsha-Project, which can be considered a milestone in research on the alleged mysterious disappearance of Nefertiti from Egyptian history, we know that the queen was still alive in the 16 Year of Akhenaten's reign. The introduction of atonism, which was so different from the old beliefs, as well as the reluctance of successive rulers towards Akhenaten, who was perceived as the heretic king, and his faithful wife, Nefertiti, make it difficult for researchers to arrive at the truth. Consequently, we must be beware of drawing any conclusions, because probably a large part of the history of the Amarna revolution has not been discovered yet. 


\section{REFERENCES}

Allen J.P.

1994 Nefertiti and Smenkh-ka-re. Göttinger Miszellen, 141, pp. 7-17.

Allen J.P.

2009 The Amarna succession. In: P.J. Brand and L. Cooper (eds.), Causing his name to live: studies in Egyptian epigraphy and history in memory of William J. Murnane, (pp. 9-20).

Arnold D. Leiden/Boston: Brill.

1996 The Royal Women of Amarna. Images of Beauty from Ancient Egypt. New York: The Metropolitan Museum of Art.

Bayer Ch.J. and Eaton-Krauss M.

2012 The Amarna triad. Revue d'Egyptologie, 63, pp. 21-41.

Blyth E.

2006 Karnak. Evolution of a temple. London and New York: Routledge.

Brunner-Traut E.

1982 Nofretete. In: W. Helck, E. Otto and W. Westendorf (eds.), Lexikon der Ägyptologie (vol. IV, col. 519-521). Wiesbaden: Otto Harrassowitz Verlag.

Collier S.A.

1996 The Crowns of Pharaoh: their Development and Significance in Ancient Egyptian Kingship. [Doctor of Philosophy Dissertation, University of California].

Cooney J.D.

1965 Amarna Reliefs from Hermopolis in American Collections. New York: The Brooklyn Museum.

Davies N. de Garis.

1903-1908 The Rock Tombs of Amarna, vol. I-VI. London.

Dodson A. and Ikram S.

1998 The Mummy in Ancient Egypt: Equipping the Dead for Eternity. London: Thames and Hudson.

Dodson A.

2009 Were Nefertiti and Tutankhaten coregents? Kemet, 20(3), pp. 41-49.

Ertman E.L.

1992 Is There Visual Evidence for a 'King' Nefertiti? In: Amarna Letters. San Francisco, 2, pp. 50-55.

Ertman E.L.

2006 Smiting the enemy in the reign of Akhenaten: a family affair. Kemet, 17(4), pp. 59-65.

Ertman E.L. and Hoffmeier J.K.

2008 A new fragmentary relief of King Ankhkheperure from Tell el-Borg (Sinai)? The Jour-

Fischer H.G. nal of Egyptian Archaeology, 94, pp. 296-302.

1977 The Orientation of Hieroglyphs. Part I - Reversals. New York: The Metropolitan Museum of Art.

Gabolde M.

2013 L'ADN de la famille royale amarnienne et les sources égyptiennes. Égypte nilotique et méditerranéenne, 6, pp. 177-203.

Gardiner A.H.

1957 Egyptian Grammar. Being an Introduction to the Study of Hieroglyphs. Oxford: Griffith Institute, Ashmolean Museum. 
Hawass Z., Gad Y.Z., Ismail S., Khairat R., Fathalla D., Hasan N., Ahmed A., Elleithy H., Ball M., Gaballah F., Wasef S., Fateen M., Amer H., Gostner P., Selim A., Zink A. and Pusch C.M.

2010 Ancestry and Pathology in Tutankhamun's Family. Journal of American Medical Association, 303(7), pp. 638-647.

Jacq Ch.

2007 Echnaton i Nefertiti. Translated by M.G. Witkowski. Warszawa: Świat Książki.

Lebek G.

2012 Schönheit, Macht und Religion: Nofretete als weibliches Gegenstück des Pharaos. Antike Welt, 6, pp. 10-12.

Loeben Ch.E.

1986 Eine Bestattung der großen königlichen Gemahlin Nofretete in Amarna? - Die Totenfigur der Nofretete. Mitteilungen des Deutschen Archäologischen Instituts Abteilung Kairo, 42, pp. 99-107.

Loeben Ch.E.

1994 Nefertiti's Pillars. A Photo Essay of the Queen's Monument at Karnak. In: Amarna Letters, 3, pp. 41-45.

Manniche L.

2010 The Akhenaten Colossi of Karnak. Cairo: The American University in Cairo Press.

Manniche L.

2010 The cultic significance of the sistrum in the Amarna Period. In: A. Woods, A. McFarlane and S. Binder (eds.), Egyptian culture and society: studies in honour of Naguib Kanawati, 2 (pp. 13-26). [Le Caire]: Supreme Council of Antiquities.

Martin G.T.

1974 The Royal Tomb at El-Amarna, vol. 1-2. London: Egypt Exploration Society.

Petrie W.M.F.

1974 Tell El-Amarna. Warminster, Wiltshire; Encino, California: Aris \& Philips, Malter.

Redford D.B.

1987 Akhenaten - the heretic king. New Jersey: Princeton University Press.

Reeves N.

2001

Samson J.

1977

Akhenaten: Egypt's False Prophet. London: Thames \& Hudson.

Schlögl H.A.

2009

Nefertiti's Regality. The Journal of Egyptian Archaeology, 63, pp. 88-97.

Starożytny Egipt. Dzieje i kultura od czasów najdawniejszych do Kleopatry. Translated by A. Gadzała. Warszawa: Wydawnictwo Naukowe PWN.

Seyfried F.

2012 Nefertiti: What remains but beauty? In: F. Seyfried (ed.), In the light of Amarna. 100 years of the Nefertiti discovery (pp. 189-194). Berlin: Ägyptisches Museum und Papyrussammlung.

Tawfik S.

1973

Aton Studies. Mitteilungen des Deutschen Archäologischen Instituts Abteilung Kairo, 29 , pp. 77-86.

Theis Ch.

2010 Das dunkle Ende einer Königin: Diskussion der Theorien zum Verschwinden der Nofretete. Kemet, 3, pp. 14-19.

The Oriental Institute

1980 The Tomb of Kheruef. Theban Tomb 192 by the epigraphic survey in cooperation with The Department of Antiquities of Egypt. Chicago: The Oriental Institute. 
Tyldesley J.

2003 Nefertiti. Stoneczna królowa Egiptu. Translated by J. Aksamit. Warszawa: Państwowy Instytut Wydawniczy.

Tyldesley J.

2006 Chronicle of the Queens of Egypt. From early dynastic times to the death of Cleopatra.

New York: Thames \& Hudson.

Van der Perre A.

2012 Nefertiti's last documented reference (for now). In: F. Seyfried (ed.), In the light of Amarna. 100 years of the Nefertiti discovery (pp. 195-197). Berlin: Ägyptisches Museum und Papyrussammlung.

Van Dijk J.

2008 A colossal statue base of Nefertiti and other early Atenist monuments from the precinct of the goddess Mut in Karnak. In: S.H. D'Auria (ed.), Servant of Mut: studies in honor of Richard A. Fazzini (pp. 246-261). Leiden/Boston: Brill.

Vosburg L.M.

2011 The sistrum as a marker of the divine nature of queenship in the Amarna Period. [Doctor of Philosophy Dissertation, The University of Memphis].

\section{ROLA NEFERTITI W RELIGII I POLITYCE OKRESU AMARNEŃSKIEGO}

\section{Streszczenie}

Głównym celem pracy jest omówienie, przeanalizowanie oraz określenie miejsca Nefertiti w religii i polityce Okresu Amarneńskiego oraz wskazanie funkcji, jakie pełniła królowa w Achetaton.

Omówione zostało pochodzenie Nefertiti. W związku z tym, że inskrypcje i dokumenty nie dostarczają informacji o jej pochodzeniu, badacze wysuwali przeróżne tezy na ten temat. Dodatkowo imię Nefertiti, Nfr-nfr.w-Itn-nfrt-iti, oznaczające Piękne jest piękno Atona, Piękna, która przybyła, inspirowało teorie o jej nieegipskich korzeniach. Sugestie te były bardzo kuszące, ponieważ tłumaczyłyby wprowadzenie na konserwatywny egipski dwór nowych, monoteistycznych wierzeń. Najprawdopodobniej królowa była córką urzędnika pałacowego z Achmim, późniejszego króla Egiptu Ai. Sugerując się najnowszymi badaniami DNA oraz danymi epigraficznymi, można wysunąć hipotezę, według której mumia z grobowca KV35, zwana Młodszą Damą (KV35YL), należy do Nefertiti.

Kolejny opisany aspekt to tytulatura królowej oraz epitety, jakimi była określana. Samo imię Nefertiti ukazuje, jak istotną rolę pełniła ona w religii i polityce przez reprezentowanie piękna boga Atona. Królowa określana była mianem Wielkiej Małżonki Króla, ale także Panią Obydwu Krajów, co wskazuje na jej wysoką pozycję zarówno w aspekcie religijnym, jak i politycznym, ponieważ w starożytnym Egipcie religia i ideologia władzy królewskiej były nierozerwalnie z sobą powiązane.

Innymi dowodami potwierdzającymi dużą rolę królowej jest scena $\mathrm{z}$ talatat pochodzącym z Hermopolis, na którym Nefertiti została przedstawiona na pokładzie ceremonialnej łodzi. Królowa trzyma jedną dłonią jeńca za włosy, a drugą ręką masakruje go mieczem chepesz. Sceny tego 
typu dotychczas, jak i w późniejszych okresach zarezerwowane były wyłącznie dla faraonów, którzy unicestwiając wrogów, jednocześnie porządkowali świat, aby zachować boski ład i porządek - maat. Nefertiti utożsamiano więc z postacią władcy. Innym dowodem na wysoką pozycję królowej są sceny polityczne, w których Nefertiti zawsze jest przedstawiana u boku Achenatona. W grobowcach Meryre (II) i Hui w Achetaton znajdują się reliefy przedstawiające sceny składania trybutu przez Nubijczyków i Syryjczyków Na reliefach para królewska została ukazana razem, a dodatkowo przedstawione postacie są tej samej wielkości.

Istotną kwestią jest przedstawienie Nefertiti w wymiarze sacrum. Najprawdopodobniej królowa została również ubóstwiona. Nefertiti razem z mężem, bogiem Atonem i sześcioma córeczkami tworzyła Enneadę, na wzór tej z Heliopolis. Achenaton był odpowiednikiem boga Szu, królowa bogini Tefnut, Aton pełnił funkcję boga Atuma, natomiast księżniczki sprawowały rolę pozostałych sześciu bóstw: Geba i Nut, Ozyrysa i Izydy, Seta i Neftydy. Wizualnym potwierdzeniem idei Szu i Tefnut jest fajansowy paciorek, na którym para królewska została przedstawiona właśnie jako para bóstw adorująca dysk słoneczny. Innym dowodem potwierdzającym ubóstwienie królowej jest tzw. aseksualny kolos z Karnaku, który obecnie identyfikowany jest jako przedstawienie Nefertiti. Królowa również w tym wypadku ma pełnić rolę bogini Tefnut, uzupełniając tym samym posągi Achenatona, który ma być uosobieniem Szu. W Karnaku powstała aleja sfinksów. Część rzeźb miała twarz Achenatona, a druga część twarz jego małżonki. Przykład ten doskonale odzwierciedla nierozłączność pary królewskiej oraz ukazuje, jak uzupełniała się wzajemnie, sprawując boską władzę zesłaną im i powierzoną przez boga Atona.

Kolejnym istotnym argumentem potwierdzającym nadanie Nefertiti boskiego statusu jest sarkofag Achenatona. Na każdym narożniku ukazano Nefertiti z rozłożonymi ramionami, obejmującą i chroniącą zmarłego władcę. Królowa antycypuje przedstawienia czterech opiekuńczych bogiń: Izydę, Neftydę, Neith i Selkit. Ozdabianie sarkofagów wizerunkami bogiń rozpoczyna się właśnie od Nefertiti. Sarkofag Tutanchamona, syna Achenatona, chroniony jest przez wspomniane wyżej bóstwa, jednak nie znamy sarkofagów sprzed Okresu Amarneńskiego, które byłyby dekorowane w ten sposób.

Badacze obliczyli, że na piaskowcowych blokach pochodzących z Hut-Benben imię Nefertiti wystąpiło prawie dwa razy częściej niż imię Achenatona, co jest doskonałym dowodem na dominację Nefertiti w zakresie funkcji, które dawniej sprawował wyłącznie faraon. Postać królowej często przedstawiana jest na reliefach w tej samej wielkości co postać jej małżonka.

Talatat, czyli piaskowcowe bloki pokryte tekstami i przedstawieniami, które przetrwały między innymi z Hut-Benben, ukazują Nefertiti spełniającą królewską rolę kapłanki w asyście najstarszej córki. Meritaton została ukazana w sposób typowy dla egipskiej Wielkiej Matżonki Króla. Nefertiti pod nieobecność męża wciela się w postać królewską, a aby dopełnić rytuału, potrzebuje towarzyszki. Sceny tego typu znane są z rekonstrukcji pylonu z Hut-Benben czy z tak zwanej kolumnady Nefertiti.

Do niedawna sądzono, że Nefertiti stała się ofiarą zarazy przywleczonej do Egiptu z Bliskiego Wschodu podczas składania trybutu przez Syryjczyków i Nubijczyków w 12. roku panowania Achenatona. Jednak niedawne odkrycie Dair al-Barsha-Project rzuca nowe światło na tajemnicze zniknięcie królowej. W wielkim Wadi Dayr Abu Hinnis na jednym ze skalnych filarów odkryto tekst datowany na 15 . dzień 3. miesiąca pory achet 16 . roku panowania Achenatona. Co najistotniejsze w 3. linii tekstu zostało napisane Wielka Mał̇onka Króla, jego ukochana, Pani Obydwu Krajów, Neferneferuaton Nefertiti. Władczyni w 16. roku panowania swojego małżonka nadal żyła i nadal była najwyższą królową. 
Artykuł omawia kilka teorii traktujących o zniknięciu Nefertiti. Przede wszystkim te, według których królowa stała się koregentem Achenatona i przyjęła imiona Anchcheperure Neferneferuaton, aby po śmierci męża objąć rządy pod imieniem Anchcheperure Semenchkare i po kilku latach przekazać egipski tron młodemu Tutanchamonowi.

Nefertiti na pewno nie była zwyczajną królową i wyróżnia się na tle innych Wielkich Matżonek. Królowa pełniła funkcje, które pierwotnie zarezerwowane były jedynie dla władcy. Zabijała wrogów Egiptu, aby zapanować nad chaosem, samodzielnie prowadziła rydwan, była przedstawiana $\mathrm{z}$ atrybutami najwyższej władzy, odprawiała rytuały i wznosiła ofiary ku czci solarnego boga, pełniła rolę bogini Tefnut oraz chroniła ciało Achenatona złożone w sarkofagu. 